\title{
Analýza rizik v novelizované normě ISO 9001
}

\author{
The Risk Analysis in New Version ISO 9001
}

Branislav Lacko*

Vysoké učeni technické v Brně, Fakulta strojniho inženýrství, Ústav automatizace a informatiky, Brno

\begin{abstract}
Abstrakt
Příspěvek popisuje novou verzi normy systémů řízení kvality ISO 9001, obohacenou o hledisko aplikace řízení rizik. Jsou vysvětleny cíle a principy tohoto př́stupu a uveden přehled souvisejících norem. Př́íspěvek doporučuje metodický postup $\mathrm{k}$ analýze rizik pomocí metody RIPRAN. Význam řizení rizik v současnosti je připomenut prostřednictvím pojmu riziková společnost, který byl definován v knize německého sociologa $\mathrm{U}$. Becka. Příspěvek byl přenesen na konferenci ExFoS 2018 a publikován ve sborníku konference, aby upozornil na aktuálnost využití rizikového inženýrství také v problematice řízení kvality.
\end{abstract}

Klíčová slova: riziková společnost, norma ISO 9001, rrízení rizik, rrízen kvality, analýza rizik, metoda RIPRAN.

\section{1. ÚVOD}

Německý sociolog Ulrich Beck již v roce 1986 ve své knize „Riziková společnost“ (český překlad [2]) poukázal na potřebu vnímat rizika, která se ve společnosti vyskytují, důkladně je analyzovat a snažit se je snížit, když už je nelze zcela eliminovat. Samozřejmě to platí i pro oblast průmyslu, zvláště proto, že současná globální tržní ekonomika je založena na riziku.

Tento nový pohled na význam a potřebu práce s riziky se postupně promítá do oblasti řízení průmyslových podniků a jiných institucí a řada dosud platných různých dokumentů je upravována z pohledu rizikového inženýrství. Týká se to i oblasti mezinárodních technických norem ISO např. oblastí bezpečnosti a spolehlivosti strojních zařízení [10], kdy dosud platné normy, preferující klasický primární pohled na konstrukční zajištění bezpečnosti používání strojů nebo zajištění jejich dlouhodobé životnosti, byly doplněny o hledisko rizika. Zmíněný aspekt rizik byl uplatněn při novelizaci normy systému rrízení kvality ISO 9001, která byla vydána organizací ISO v roce 2015 a následně akceptována jako národní norma ČSN v roce 2016.

\begin{abstract}
The contribution deals with the risk engineering approach in new version ISO quality management standard 9001 . Goals and principles the risk point of view and other connected ISO risk standards with the new standard are described. The method RIPRAN is recommended. The term risk society by german writer $\mathrm{U}$. Beck is mentioned as expression for current social situation. The paper was presented at XXVII. International conference ExFoS 2018 and was published at the conference proceeding.
\end{abstract}

Keywords: risk society, standard ISO 9001, risk management, quality management, risk analysis, RIPRAN method.

\section{RIZIKA PŘI ZAJIŠŤOVÁNÍ KVALITY}

\subsection{Rizika kvality ve standardech před novelizací}

Stále zvyšující se požadavky na kvalitu výrobků a procesů, nutně vedly k situaci, kdy se zvyšovalo nebezpečí, že náročné požadavky zákazníků nebudou splněny. Rizika si intuitivně uvědomovali pracovníci, kteří byli pověřeni zajišt'ováním vysoké kvality výroby.

Již v roce 1992 vznikla metoda FMEA (failure mode and effects analysis) [11], kde byla popsána analýza způsobů a důsledků poruch, včetně kritičnosti poruch, a uveden návod, jak předcházet rizikům př́padných negativních dopadů.

Na tuto normu navázal popis metody analýzy stromu poruchových stavů (FTA - Fault tree analysis) [12], která se zabývá identifikací i analýzou podmínek a faktorů, které způsobují nebo mohou potenciálně způsobit výskyt, př́padně přispívat k výskytu, specifikované vrcholové události. Při analýze FTA je touto událostí obvykle zhoršené fungování systému, snížení bezpečnosti nebo zhoršení jiných důležitých provozních atributů, zatímco při analýze STA (Success Tree Analysis - analýze stromu úspěchů) je touto událostí atribut popisující bezporuchový stav. 
Následně byla v roce 1997 vytvořena $\mathrm{v}$ rámci podpůrných standardů, které podporovaly zavádění systémů řízení kvality podle normy ISO 9001, norma ISO 10006 [2]. Tato norma uváděla seznam procesů, které je nutno dobře provádět, má-li se zajistit kvalitní výrobek, vyráběný jako výsledek projektu. Zároveň upozorňovala na potřebu realizovat vlastní návrh souboru firemních směrnic procesů $\mathrm{k}$ zajištění kvality jako dobře naplánovaný a řízený projekt. V ní byl jako jeden z kritických procesů zmíněn postup řízení rizik. Bohužel proto, že se zmiňovala o projektech, bylo řízení rizik, jak certifikačními firmami, tak certifikovanými firmami, vztaženo jen na projekty, nikoliv i na vlastní procesy řízení kvality! ${ }^{1)}$.

\subsection{Pojetí rizik v novelizované normě ISO 9001:2015}

Teprve poslední platná - v pořadí pátá - novelizace standardu ISO 9001, explicitě zařadila problematiku rizik do textu normy jako jednu z charakteristických prvků této novelizace, jak je to zdůrazněno hned úvodní kapitole novelizované normy, a upozornili na to také autoři publikací o novelizované normě $[6,7]$.

Podrobněji zásadu „Zvažování rizik - Risk based thinking“ rozvádí novelizovaná norma v odst. 0.3.3 kapitoly Úvod (str.13): „Zvažování rizik je nezbytné pro vybudování efektivního systému managementu kvality. Koncepce zvažování rizik byla $\mathrm{v}$ předchozích vydáních této normy obsažena implicitně, zahrnovala např. provedení preventivních opatření k odstranění potenciálních neshod, analyzování veškerých vyskytnuvších se neshod a přijetí opatření odpovídajících následkům neshody, které mají zabránit opakovanému výskytu. Aby organizace vyhověla požadavkům této mezinárodní normy, musí plánovat a realizovat opatření pro řešení rizik a př́ležitostí. Řešení jak rizik, tak př́ležitostí, vytváří základ pro zvyšování efektivnosti systému managementu kvality, dosahování lepších výsledků a předcházení negativním účinkům.“

Autorka publikace [7] M. Becková správně zdůrazňuje na str. 12 v 3. odst. shora významnou skutečnost: „že systematický př́stup $\mathrm{k}$ riziku je jednou z klíčových změn v revizi normy ISO 9001:2015“!

Protože si tvůrci textu českého textu normy uvědomovali, že pro řadu našich firemních pracovníků bude problematika řízení rizik zcela novou, dřive neznámou, je v národní předmluvě ČSN EN ISO 9001 [1] na str. 2 uvedena v seznamu souvisejících mezinárodních standardů norma ČSN ISO 31000 [3], popisující zásady, principy a doporučené pokyny pro management rizik, která ve svém textu doporučuje normu ĆSN EN 301010 [4], obsahující přehled technik pro posuzování rizik.

Text normy ČSN EN ISO 9001 [1] v kap. 3 na straně 15, neuvádí př́ímo výčet používaných termínů a definic, ale odkazuje na normu ISO 9000:2015, kde je riziko definováno v odst. 3.7.9 jako efekt nejistoty na očekávaný výsledek, v souladu s ISO 31000 a navazující terminologickou normou rizik ISO 73:2009.

\subsection{Analýza rizik v novelizované normě ISO 9001:2015}

Systémový př́stup $\mathrm{k}$ aplikaci rizik $\mathrm{v}$ rámci normy pro systémy ř́zení kvality vedl tvůrce textu novelizovaného standardu k tomu,

\footnotetext{
Je nutno poznamenat, že v důsledku neznalosti zásad současného projektového řízení, norma ISO 10006 nebyla aplikována ani certifikačními firmami, ani certifikovanými, ani v těch př́padech, kdy výsledné produkty byly de facto realizovány jako projekty! Takže nebyly nastaveny ani procesy řízení projektových rizik!
}

aby vložili požadavky na analýzu rizik do jednotlivých skupin činností, které mají zajistit efektivní rízení procesů vysoké jakosti.

Konkrétně jsou to následující části textu normy, kromě zmíněných úvodních deklarativních odstavců:

- Odst. 4.4 Systém managementu kvality a jeho procesy v pododstavci 4.4.1 bod f) řešit rizika a př́ležitosti v souladu s požadavky 6.1 Opatření pro řešení rizik a př́ležitosti

- Odst. 5.1.2 Zaměření na zákazníka bod b) určení rizik a př́ležitostí, které mohou ovlivnit shodu produktů a služeb a schopnost zvyšovat spokojenost zákazníka.

- Kap. 6 Plánování obsahuje odst. 6.1 Ošetření pro řešení rizik a př́ležitostí a odst. 6.2 , které specifikují činnosti pro rizika při plánovacích aktivitách.

- Odst. 9.1.3 Analýza a hodnocení má bod e) hodnotit efektivnost přijatých opatření pro řešení rizik a prríležitostí, což má zajistit neustálé zlepšování procesů, které jsou spojeny s řízením rizik.

- Odst. 10.2 Neshody a nápravná opatření obsahuje v odst. 10.2.1 bod e) aktualizovat rizika a př́ležitosti určené v průběhu plánování, je-li to zapotřebí.

V př́loze A č. 4 norma podrobněji rozvádí pojetí „Zvažování rizik“, které bylo uplatněno v novelizované normě ve srovnání $\mathrm{s}$ předchozími verzemi. $\mathrm{V}$ závěru př́lohy jsou organizace, které budou využívat tuto normu, vyzývány, aby zvážily, zda a jak mají uchovávat dokumentované informace jako důkaz o určování rizik. Jedná se v podstatě o stanovení formy a rozsahu tzv. registru rizik.

\subsection{Používané metody pro analýzu rizik v rámci novelizované normy ISO 9001:2015}

Vydaná novelizace ISO 9001 nepředepisuje metody, které by organizace musely používat při analýze rizik. Předpokládá, že pracovníci firem si z nabídky exitujících metod vyberou takovou, která optimálně bude vyhovovat jejich konkrétním požadavkům a použití této metody jim přinese maximální efekt.

Norma ISO 31010 [4] poskytuje obecný přehled doporučovaných postupů rizikového inženýrství pro tyto případy. Publikace M. Beckové [7] uvádí její vlastní doporučovaný postup přímo pro aplikaci v rámci novelizované normy ISO 9001 včetně několika př́kladů použití.

Autor tohoto př́ispěvku může doporučit používání jím vyvinuté metody RIPRANTM 2), za kterou byl jmenován finalistou FERMA AWARD 2016 v kategorii „Innovative Insurance Programme of the Year" (FERMA - Federation Evropean Risk Manager Association sdružuje rizikové manažery v Evropě), která se již 15 let používá u nás $\mathrm{k}$ analýze rizik [8].

I když norma nenařizuje konkrétní metody pro analýzu rizik, na druhé straně zásada č. 4 Procesní př́istup v ISO 9000 jednoznačně vyžaduje, aby nebyl aplikován nahodilý postup založený na intuici, ale systémová analýza rizik podle některé uznávané metody a v rámci firmy stanovený systematický postup řízení rizik.

Rizika zainteresovaných stran v rámci novelizované normy ISO 9001:2015

Novelizovaná norma zařadila nově do textu standardu v kap. 4 problematiku kontextu organizace, ve které je systém řízení

2) RIPRANTM je ochranná známka vydaná Úřadem pro průmyslové vlastnictví Praha pod. č. 283536. 
kvality zaváděn. Jedná se o to, že organizace musí určit interní a externí aspekty, které jsou významné pro její cíle a strategické záměry, a musí monitorovat a přezkoumávat informace o těchto aspektech. Jinak se vystavuje riziku, že opomene učinit opatření proti dopadu některých negativních aspektů, nebo riskuje nevyužití positivních faktorů v prospěch zavádění firemní kvality. Aspekty mohou být právního, technologického, konkurenčního, tržního, kulturního, sociálního, ekonomického i politického druhu. Odst. 4.2 Porozumění potřebám a očekáváním zainteresovaných stran ukládá jednak určit tyto strany, jednak analyzovat jejich potřeby a očekávání, aby se předešlo riziku, že budou ignorovány při návrhu a realizaci systému řízení kvality.

Hledisko zohlednění potřeb a požadavků zainteresovaných stran, vyplývá z principu realizace systému řízení kvality jako projektu, který zvažuje nejen vliv stran, které se podílejí na realizaci projektu, ale i stran dotčených projektem (stakeholders), protože je důležité předejít riziku konfliktu s dotčenými stranami, které v současné legislativě mají poměrně rozsáhlé pravomoci.

\section{ZÁVĚR}

Jak bylo uvedeno v úvodu tohoto článku, současná novelizace normy ISO 9001 je dalším krokem, kterým mezinárodní společnost pro technicko - organizační normy ISO reaguje na současnou důležitost práci s riziky. Právě skutečnost, že se tak děje v souvislosti s problematikou zajišt'ování kvality zdůrazňuje, že i rizika mají být řízena kvalifikovaně a kvalitně! Po obecných normách o rizikovém inženýrství $[3,4,11,12]$ a po výzvě $\mathrm{k}$ aplikaci řízení rizik v souvislosti s projektovým řízením [2, 5], je řízení rizik explicitně vyžadováno i v oblasti řízení kvality firemních produktů a procesů.

Je s podivem, že řada pracovníků vrcholového vedení našich firem považuje stále tyto kroky za izolovaná opatření ve vyjmenovaných oblastech, dokonce někteří z těchto pracovníků, je vnímají jako kroky zbytečné! V řadě našich firem ještě nebylo zavedeno integrované řízení všech firemních rizik (viz např. publikaci [13]), jak je to běžné v praxi západních firem (corporate risk management). Projekty se ještě stále ve většině firem provádějí intuitivně bez aplikace mezinárodních přístupů a metod k současnému projektovému řízení podle normy ISO 21500 a bez kvalifikované analýzy rizik. Ale současné ekonomické globální prostředí už nejen v současnosti, ale zejména v budoucnosti, předpokládá využívání sjednoceného mezinárodního př́ístupu k projektům a využívání progresivních postupů pro jejich plánování a implementaci [14].

\section{LITERATURA}

[1] ČSN EN ISO 9001 (01 0321) Systémy managementu kvality Požadavky. Úřad pro technickou normalizaci, metrologii a státní zkušebnictví, Praha, 2016, 48 s.

[2] ČSN ISO 10006 (01 0333). Management jakosti-Směrnice jakosti v managementu projektu. Úřad pro technickou normalizaci, metrologii a státní zkušebnictví, Praha, 1999, 36 s.

[3] ČSN ISO 31000 (01 0351) Management rizik - principy a směrnice. Úřad pro technickou normalizaci, metrologii a státní zkušebnictví, Praha, 2010, 37 s.

[4] ČSN EN 31010 (01 0352) Management rizik-Techniky posuzování rizik. Úřad pro technickou normalizaci, metrologii a státní zkušebnictví, Praha, 2011, 80 s.

[5] ČSN ISO 21500 (01 0345) Návod k managementu projektu. Úřad pro technickou normalizaci, metrologii a státní zkušebnictví, Praha, 2013, 66 s.

[6] Kol. autorů: Komentované vydání normy ČSN EN ISO 9001:2016. Česká společnost pro jakost, 2016, Praha, 136 s., ISBN 978-80-02-02642-6.

[7] BECKOVÁ, M. Revize ISO 9001:2015. Verlag Dashöfer, Praha, 2016, 92 s. ISBN 978-80-87963-22-7.

[8] LACKO, B. Využívání metody RIPRAN při analýze rizik projektů. Sborník př́spěvků 1. konference „,Rizika podnikových procesů-RPP2011 “, Univerzita J. E. Purkyně, Ústí nad Labem 2011. ISBN 978-80-7414-371-7.

[9] BECK, Ul. Riziková společnost. 2. vyd., Vydavatelství Slon, Praha, 2011, 431 s. ISBN 978-80-7419-047-6.

[10] LACKO, B. Rizikové inženýrství a nové pohledy norem ISO na bezpečnost strojních zařízení. Sborník konference ExFos 2016, ÚSI VUT v Brně, Brno, 2016, s. 429-435, ISBN 978-80-214-5321-0.

[11] ČSN EN 60812 (010675) Techniky analýzy bezporuchovosti systémů - Postup analýzy způsobů a di̊sledkü poruch (FMEA). Český normalizační institut, Praha, 2007, 43 s.

[12] Č́SN EN 61025 (01 0676) Analýza stromu poruchových stavi (FTA). Český normalizační institut, Praha, 2007, 44 s.

[13] SMEJKAL, V., RAIS, K. Řizení rizik ve firmách a jiných organizacích. 4. vydání, Grada Publishing, Praha, 2013, 488 s. ISBN 978-80-247-4644-9.

[14] MARSINA, Š., HAMRANOVÁ, A. Perspectives of building project orientation of an organization and its technological support. Volters Kluver, Praha, 2016, 136 s. ISBN 978-80-7552-549-9. 